\title{
Evaluation on the Impact of GST on Restaurant Business in Tambaram, Chennai
}

\author{
Gowtham Aashirvad Kumar, A.Ravikumar,S.Mugundhan
}

\begin{abstract}
To find out the impact of GST on restaurants in Chennai. To find out the post GST charges in the restaurants.To find out the satisfaction of the restaurants owners with the post GST charges.To find out the satisfaction of the customers with the post GST charges. To suggest suitable measures for better restaurant business in Chennai.
\end{abstract}

Keywords :GST,Restaurant,Charges..

\section{INTRODUCTION}

The Indian restaurant sector is worth Rs. 75,000 and grows at an annual pace of $7 \%$. With 1.5 million eating outlets, the company is extremely divided. According to the 2013 Indian Food Services Report of NRAI, the sector presently uses 4.6 million individuals directly, which is expected to expand to 8 million by the 2013 Indian Food Services Report of NRAI.. If you've been to any restaurant or cafe, post GST rollout on July 1 , your bill looked distinct from what it looked like previously. Several months have passed since the historic Goods and Service Tax or GST was enacted in India at a historic midnight bash in New Delhi Parliament's Central Hall. Under the new tax system, the goods have been classified into five categories: those exempted from tax, $5 \%$, $12 \%, 18 \%$ and $28 \%$. Along with other industries, GST will be applied to the F\&B (Food and Beverage) sector of the nation from 1 July 2017 onwards. GST will impact both restaurant industry vendors and consumers alike.[1-5]

Pre-GST, it was simple to eat at a restaurant. You've got your food, you're paying and you're leaving. You had to pay three additional fees back then: service charge, service tax and VAT. However, by having them pay extra, the complicated nature of GST has provided restaurant owners the chance to cheat their clients.[6]

\section{II.WHAT IS GST}

Goods and Services Tax is a one-time tax scheme that would eliminate all other federal and state taxes. The GST Council has completed a four-tier tax system in which taxes will be levied at 5, 12, 18 and 28\%. Essential items, including food, that are Approximately half of the consumer inflation basket and significant food grains were exempted from GST and taxed at zero prices. The smallest $5 \%$ tax slab will only apply to products of common use, whereas the largest $28 \%$ slab tax will be levied on luxury products such as aerated beverages and tobacco. Before GST was brought in, your restaurant bill

Revised Manuscript Received on July 22, 2019.

Gowtham Aashirvad Kumar Department of Management studies,Bharath Institute of Higher Education and Research,Chennai,India

A.Ravikumar, Department of Management studies,Bharath Institute of Higher Education and Research,Chennai,India

S.Mugundhan, Department of Management studies,Bharath Institute of Higher Education and Research,Chennai,India had a amount of taxes[9]. Service tax, VAT, Cess KrishiKalyan and Cess Swachh Bharat were charged. Under the VAT system, a complete tax of around $20.5 \%$ on your restaurant outing was relevant. Restaurants used to pay a service fee of 10 percent. That could be overlooked as it is not a state levied tax. But, the restaurant owners would include the service charge in the bill and apply service tax on that service charge too. Since the levy of service charge is not banned and is made voluntary for customers, it can still be included in the bill. The customers will therefore pay a single tax on the total food bill and additional service charge in the new regime if they wish.[10]

\section{III.TAX RATES}

- Depending on their turnover and whether or not they have air conditioning, there are distinct tax sheets for restaurants.

- Restaurants with a turnover of less than Rs 50 lakh are charged a tax rate of $5 \% ;[11]$

- Non-AC restaurants are charged a tax of $12 \%$;

- AC and liquor licensed restaurants will have a tax rate of $18 \% ; \cdot 5$-star hotel restaurants will have a GST rate of $28 \%$.

Under the GST regime, the tax rate will be liveable as service delivery, not as transaction value delivery of goods. Restaurant services were defined as a composite service.

GST rates and how they apply:[12]

The GST system splits restaurants into two categories: air conditioning and air conditioning. Besides that, there are sub-categories for institutions that are part of $\mathrm{AC}$, those that serve alcohol or do not serve alcohol and restaurants with five stars.

Non-air-conditioned facilities: alcohol-free facilities will charge GST at $12 \%$ (Central GST at 6\% and State GST at 6\%) while alcohol-free institutions will charge GST at $18 \%(9 \%$ CGST and 9\% SGST). Five-star air-conditioned, partially air-conditioned air-conditioning: these institutions will charge GST at 18\% (9\% CGST and 9\% SGST) regardless of the accessibility of alcohol for employers. This reduces the tax on restaurant outings from $20.5 \%$ to $18 \%$.[13]

According to GST laws, restaurant owners in the restaurant industry are liable to pay full-rate supply tax from unregistered persons under reverse charge mechanism (RCM) as restaurant owners have to make a lot of supplies from unregistered individuals.Composition holders are not responsible under the VAT system to pay purchase tax on transactions made by unregistered individuals. [14]The composition of Rs. 75 Lakh is too small to obtain the true advantage. Restaurants enjoy greater boundaries with reduced tax rates under VAT legislation.[15] Under the GST system,

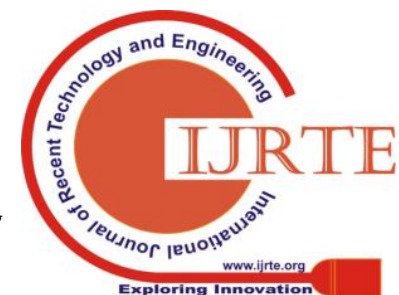


restaurant service suppliers and hoteliers are facing actual hardship with a greater tax burden on external supplies. There will also be compliance problems under the GST system where the provider must retain meticulous records and paperwork to claim Input Tax credit and also comply with the various regulations of the GST legislation.

Restaurant facilities have always been a controversial service under current legislation. It is one of those facilities where both are charged VAT and service tax. Under GST legislation, however, the government has attempted to simplify the legislation to minimize unwanted conflicts.

Under GST, restaurant services are categorized into four parts:[16]

- Food / drink supply in restaurants without AC and licensed to serve alcohol - Food / drink supply in restaurants licensed to serve liquor - Food / drink supply in restaurants with AC facilities at any moment during the year.[17]

- Supply of goods / drinks in a 5-star or above-rated restaurant Here is an assessment of the effect on something that is very close and dear to us, or rather to our stomachs, the restaurant and food industry. Let's find out how our restaurant outing impacts the application of GST? What does this mean for the restaurants company? Must we get a larger hit on our pocket? For restaurants and food outings, this is what GST will mean.

\section{IV.NEED OF THE STUDY}

The Restaurant Industry is currently burdened with a host of taxes at each and every point- right from the purchase of the raw materials to the sales of finished items.[19] Multiple taxes, in turn, charged from the customers at the final bill are a huge turnoff for the customers and play a major role in turning them away.Another important reason for this study is due to Complex nature of GST, which has offered restaurant owners so many opportunities to cheat their clients by having them pay extra. So, here's all you need to understand to be on the smarter side:

\section{V.SCOPE OF THE STUDY}

GST being a trending concept has attracted a lot of confusions and scepticism from various industries, which includes the restaurant industry as well, and these queries have bombarded us, which in turn has prompted us to launch a full-fledged discussion on GST. This article covers the GST FAQs and would provide you a pathway into the intricacies of the concept of GST.[20]

The research is carried out to analyze the efficacy of VAT implementation. It includes restaurant owners ' views, restaurant staff and the general public, consumers. It reveals the positive effects of VAT. The reason for the shift from VAT to GST is highlighted in this research. This research is being performed in relation to Tamil Nadu and Tambaram State, especially Chennai.[21]

\section{LIMITATIONS}

This research study refers only to the intrinsic weakness of the main information source. The respondents ' insufficient understanding of VAT policies, processes and techniques is likely to influence the general public's reaction. The samples and the collection of information are based on the respondents ' readiness and responses. The VAT administration method is an ongoing method and the data gathered based inferences and findings may not represent the course of action in the future. Since the reforms are of a continuous nature, the findings of the study may change from time to time in the right to evaluate data.[22]

\section{VII.REVIEW OF LITERATURE}

Briefreviewofliteratureofgstinindia:

in2000, theVajpayeeGovernmentstarteddiscussion on GST through the establishment of an authorized commission. P.Chidambaram, the then Minister of Finance of the Union, produced an announcement during the 2007-2008 central budget that it would be implemented from 1 April 2010. Following this announcement, the State Finance Ministers ' Empowered Committee decided on May 10, 2007 to set up a Joint Working Group with the Union Advisor Finance Minister and the Member Secretary of the Empowered Committee

[23] asco-convenersandtheconcernedJointSecretariesof theDepartmentofRevenueofUnionFinanceMinistry and all the Member States ' Finance Secretaries. CenterIncludedCompensation in GST Constitutional Amendment Bill, therefore compensation will be paid to countries for loss of income due to the roll-out of the new indirect tax scheme. Liquor was an integral part of the GST. John Mathai Committee (1953): On April 1, 1953, under the chairmanship of John Mathai, the Government of India appointed the Taxation Inquiry Commission. The commission's terms of reference were to examine the incidence and appropriateness of the Central State and Local taxation of different classes of persons and, in particular, of (a) the modifications required by the current taxation system and (b) the fresh taxation avenues. The commission produced several government suggestions.[24]

M. GOVINDA RAO8 (2000) For a multitude of reasons, his paper entitled ' Tax reform in India: accomplishments and difficulties ' highlights significant changes in tax schemes in a number of nations over the past two decades. This paper's objective is to analyze the evolution of India's tax system since the early 1990s. This paper describes and evaluates the introduction of new forms of direct and indirect taxes, their impact on income and equity, and the successes achieved in implementing them. The article concludes that a significant challenge in India continues after eight years of reforming the tax system.[25]

C.A. SUDHIR HALAKHANDI10 (2009) In his article entitled' Goods and Service Tax-An Introductory Study,' this paper focuses on how this tax scheme will operate and discusses the issues that the central government is likely to face when implementing this tax. It also touches briefly on VAT and Central Service Tax at the current state level. He points out that there is no fundamental distinction between the current VA tax system And GST as regards goods tax, as GST is also a type of VAT on products and services. In this case, the sales tax, with the exception of CST, is a VAT system, and in the case of service tax, the system also has the CENVAT credit system, which means that both sales tax and service tax are subject to VAT in our country.

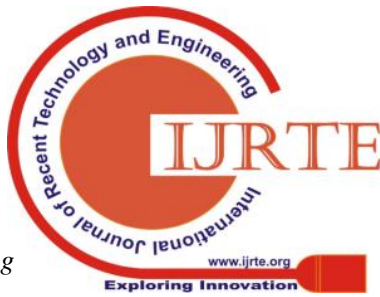


The products and services are currently taxed individually, but the distinction in GST will disappear. GST's general scheme is very comparable to VAT, which can be seen as a first step towards GST.[26]

ABEHODIE YESEGAT (2008) This article examines VAT administration in Ethiopia and identifies important issues including a absence of adequate amount of qualified staff and administrative gaps in fields such as demands for refunding, invoicing and filing. Data acquired through in-depth interviews with tax authorities and surveys were used to examine VAT procedures in Ethiopia and identify key issues 269 taxpayers and 33 tax professionals were the sample size for the taxpayer and tax practitioner surveys. This document indicates that trying to enforce the laws in the primary fields (such as refunds) in Ethiopia deserves due attention from the governmentThe research also highlights the need to reinforce the overall administrative ability and, in specific, the tax audit program. As a manner forward for future studies, the article evaluates the allocation of VAT income to regional governments and the decentralization of their administration.[27]

ANDREW M C SMITH (2011) This document reviews the fundamental composition of Bangladesh's VAT scheme and attempts to analyze the contribution and efficiency of VAT in Bangladesh as compared to other developing nations, as well as to recognize and provide recommendations in areas where attention and enhanced results are needed to improve the contribution of VAT to Bangladesh's financial growth.. The appropriate information indicates that the VAT output in the original years was quite satisfactory-but the collection of VAT eventually stagnated at a certain point. As a result, VAT can not fulfill the goals it was implemented for. There are many explanations for this performance, for example: a comparatively tiny number of VAT taxpayers, a general lack of consciousness and a weak monitoring systemThere is still room for enhancing VAT income collection: by reducing the amount of VAT taxpayers ; by reforming the VAT administration ; by raising people's consciousness, by revisiting the list of products exempted from VAT and by enhancing the surveillance system's effectiveness.[28]

JAIDEEP MISHRA11 (CBEC) In its concept document titled ' Central Board of Excise and Customs, ' 2011 emphasizes that maintaining certain service suppliers outside the tax chain would boost the efficient tax on complete production by precluding tax credit benefits at later production phases. An effective tax set-off system would encourage the procurement of the most efficient suppliers and would discourage doing everything at home. By definition, a service is considered to be anything that is not a supply of goods, money or immovable propertySave for three specific instances: in the case of an employee and employer, provided by a constitutional authority, etc., or by local authorities, and labeled as manufactured in accordance with the Central Excise Act.

Thirteenth finanace commission on national council of applied economic research in their report12 (2009) Refers to the wide goals of this research in analyzing the effect of the introduction of Comprehensive Goods and Services Tax (CGST) on economic growth and international trade ; changes in production factor incentives ; and sector-level output, prices, capital, jobs, effectiveness and international trade. Analysis in this research shows that implementing a extensive GST in India is anticipated to result in an effective distribution of manufacturing variables leading to GDP and export profits. This would translate into improved economic welfare and return to production factors, that is to say. land, labour and capital.

In their research article "A study on goods and service tax in India," Neha and Manpreet Sharma describe GST. They attempted to figure out the advantages of GST and GST's current status in India. According to them, owing to flaws in our present indirect tax system, we move towards GST. Our current indirect tax structure can not improve industry competitiveness. Both emphasize GST's advantages. In "Global Journal of Multidisciplinary Studies," Vol, Nitin Kumar writes a research paper entitled "Goods and Service Tax in India-A Way Forward." 3, Issue6, May 2014, and he stated that implementing GST in India would be a major step and would eliminate the whole issue of current tax structure in India.

\section{VIII.RESEARCH METHODOLOGY}

The method used to gather information and data for company decision-making purposes. The methodology may include research on publications, interviews, surveys and other study methods, and may include both current and historical data. A summary of the methodology followed in carrying out the project will be discussed in detail in this project. The type of project, the target respondents, the hypotheses and constraints in the execution of the project, the techniques for obtaining the information and the multiple instruments used to reach the conclusion[29]

\section{IX.TYPE OF PROJECT}

Research is therefore an initial contribution to the design of motivational variables that work in restaurants. It is the pursuit of reality by studying, observing, comparing and experimenting with it. In brief, study is also the quest for information through objective and systematic generalization technique and the formulation of a theory.

This sort of study is tentative and in nature qualitative. Exploration is especially helpful when scientists lack a clear understanding of the issues. The strategy used in the research was both qualitative and quantitative, since only theoretical elements are not taken into account, but their practicality is also noted. Exploratory research may create hypothesis, but it is not attempting to test it. Flexibility characterizes exploratory studies.[30] Although cash is a very helpful incentive instrument to improve the motivation of employees It doesn't work for all. GizelaHagemannová (1995) and many other theorists argue that concrete incentives operate until an employee's experience lacks cash for their living standards. Therefore, one can suppose that cash would be a very useful motivator for normal employees, but would not be as strong motivator for executives, who usually receive enough cash to cover their requirements and are therefore able to give them to search for other particular characteristics. Organizations need to look for various incentives for this purpose, which would give managers the impression that their organisation appreciates them. These are known as intangible benefits.[31] 


\section{$X$.RESEARCH DESIGN}

The current research is primarily interested in finding out about human resource management operations according to the goals: employee motivation in restaurant Dominos. The investigator decided to use the descriptive research design to meet the study's goals. (Survey technique) to acquire information to achieve the correct research outcomes. Descriptive research (survey method) is regarded a suitable method for acquiring specific information on this study scenario.

\section{XI.TARGET RESPONDENTS}

The respondents were selected randomly from Restaurants, Tambaram, Chennai. The research questions are set to gather verdicts of employees in restaurant regarding knowledge transfer process.

\section{METHOD OF DATA COLLECTION}

a) Primary data: Primary data is the basis of the present study. Questionnaire is considered to be the primary data collection tool. The questionnaire was systematically intended Covering almost all elements of the research adequately and applicable. The primary source information was arranged sequentially and systematically tabulated.

b) Secondary data: Secondary data needed for the study from books, newspapers, previous studies, reports and websites.

TABLE NO. 1: TYPE OF RESTAURANT RESPONDENTS

\begin{tabular}{|l|l|l|l|l|l|}
\hline S.NO & $\begin{array}{l}\text { TYPE OF } \\
\text { RESTAURANT }\end{array}$ & \multicolumn{2}{l|}{ RESTAURANR CUSTOMERS } & \multicolumn{2}{l|}{ RESTAURANT EMPLOYEES } \\
\cline { 3 - 7 } & $\begin{array}{l}\text { NUMBER OF } \\
\text { RESPONDENTS }\end{array}$ & $\begin{array}{l}\text { PERCENTAGE } \\
(\%)\end{array}$ & $\begin{array}{l}\text { NUMBER OF } \\
\text { RESPONDENTS }\end{array}$ & $\begin{array}{l}\text { PERCENTAGE } \\
(\%)\end{array}$ \\
\hline 1 & AC & 35 & 58.3 & 14 & 70 \\
\hline 2 & NON AC & 25 & 41.7 & 6 & 30 \\
\hline & 60 & 60 & 20 & 100 \\
\hline
\end{tabular}
CHART NO. 1: TYPE OF RESTAURANT
RESPONDENTS

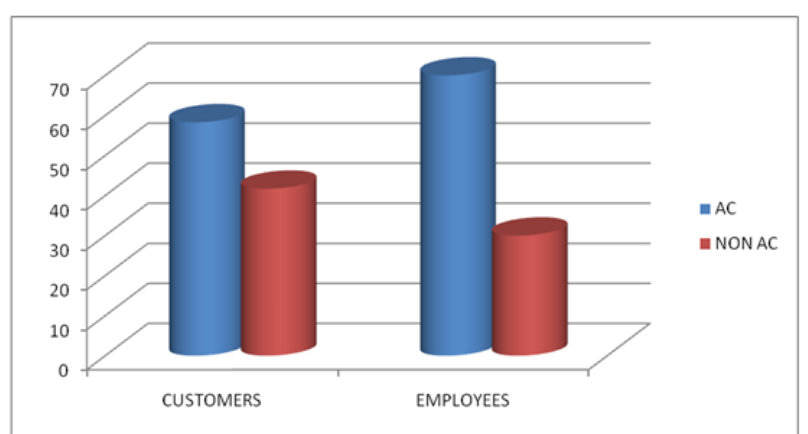

INFERENCE: $58.3 \%$ of customer respondents are from AC category restaurants and $41.7 \%$ of customer respondents are from Non AC restaurants. While, $70 \%$ of restaurant employee The participants are in the AC category and $30 \%$ of the participants in the restaurant are in the Non AC category.

TABLE NO. 2: WERE YOU SATISFIED WITH PRE-GST RATES?

\begin{tabular}{|l|l|l|l|l|l|}
\hline S.NO & WERE & \multicolumn{2}{|l|}{ AC } & \multicolumn{2}{l|}{ NON AC } \\
& $\begin{array}{l}\text { YOU } \\
\text { WITH } \\
\text { PRE-GST } \\
\text { RATES? }\end{array}$ & $\begin{array}{l}\text { NUMBER OF } \\
\text { RESPONDENTS }\end{array}$ & $\begin{array}{l}\text { PERCENTAGE } \\
(\%)\end{array}$ & $\begin{array}{l}\text { NUMBER OF } \\
\text { RESPONDENTS }\end{array}$ & $\begin{array}{l}\text { PERCENTAGE } \\
(\%)\end{array}$ \\
\hline 1 & $\begin{array}{l}\text { Strongly } \\
\text { dissatisfied }\end{array}$ & 6 & 12.2 & 1 & 3.2 \\
\hline 2 & Dissatisfied & 8 & 16.3 & 3 & 9.7 \\
\hline 3 & Neutral & 12 & 24.5 & 7 & 22.6 \\
\hline 4 & Satisfied & 14 & 28.6 & 12 & 38.7 \\
\hline 5 & $\begin{array}{l}\text { Strongly } \\
\text { Satisfied }\end{array}$ & 9 & 18.4 & 8 & 25.8 \\
\hline & & 49 & 100 & 31 & 100 \\
\hline
\end{tabular}

CHART NO. 2: WERE YOU SATISFIED WITH PRE-GST RATES?

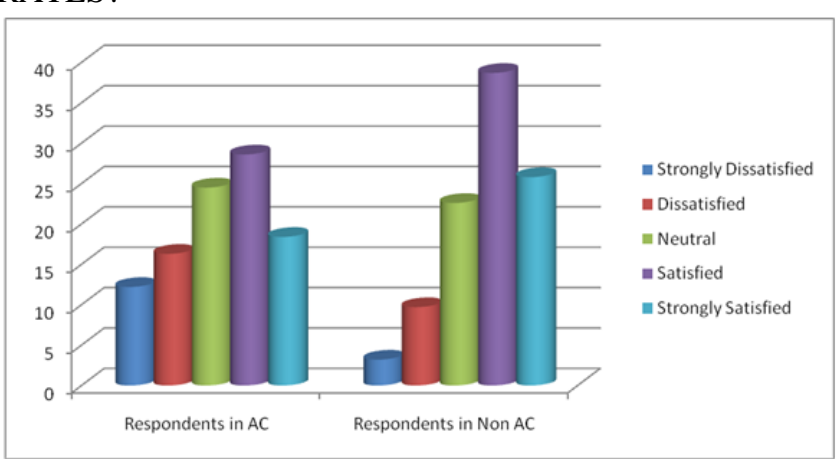

INFERENCE: In both the AC and Non-AC restaurants, we see that the customers as well as employees had no objection of the Pre-GST rates (VAT and service tax) and in some restaurants service charge as well.

CHART NO. 3: ARE YOU SATISFIED WITH THE POST-GST RATES?

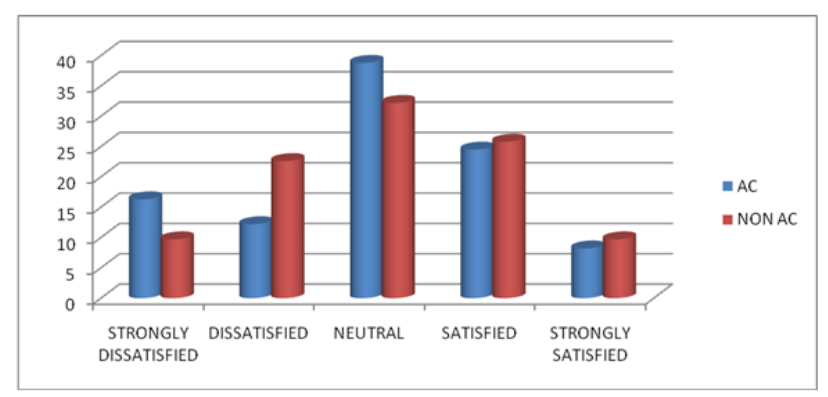

INFERENCE: In both the AC and the Non AC restaurants, we know from the table no. 5 that 80 respondents inclusive of both the customers and employees staff had given their opinions, but what it has been found out is that still many are unaware of which tax is higher.

TABLE NO. 3:HOW LIKELY WILL YOU VISIT RESTAURANTPOST-GST

\begin{tabular}{|c|c|c|c|}
\hline \multirow[t]{2}{*}{ S.NO } & \multirow{2}{*}{$\begin{array}{lc}\text { HOW LIKELY } & \text { WILL } \\
\text { YOU } & \text { VISIT } \\
\text { RESTAURANT } & \text { FROM } \\
\text { NOW ON } & \end{array}$} & \multicolumn{2}{|l|}{ CUSTOMERS } \\
\hline & & $\begin{array}{lr}\text { NUMBER } & \text { OF } \\
\text { RESPONDENTS }\end{array}$ & PERCENTAGE (\%) \\
\hline 1 & Definitely will & 24 & 40 \\
\hline 2 & Probably will & 21 & 35 \\
\hline 3 & May or may not & 12 & 20 \\
\hline 4 & Probably will not & 2 & 3.3 \\
\hline 5 & Definitely will not & 1 & 1.7 \\
\hline & & 60 & 100 \\
\hline
\end{tabular}


CHART NO. 4:HOW LIKELY WILL YOU VISIT RESTAURANT POST-GST

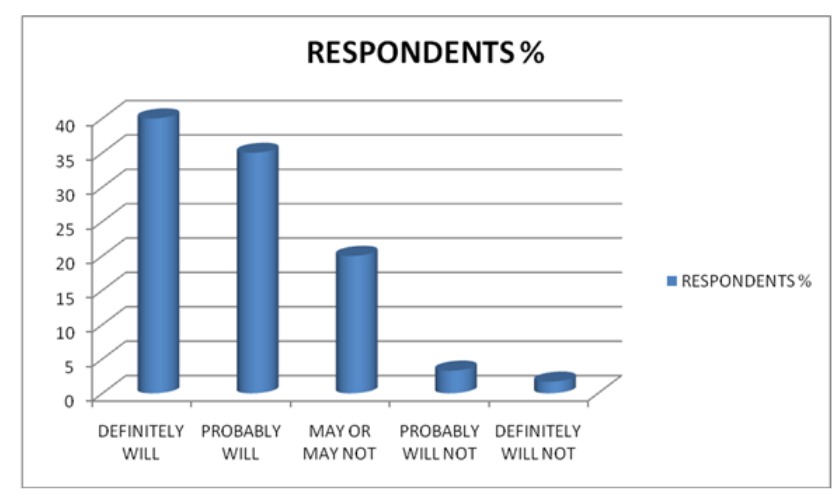

INFERENCE: Even after Post-GST, we find that it makes no big issue to food lovers as no matter how much higher or lower is the taxation; they will still continue to visit restaurants. $40 \%$ of the respondents have responded very positively followed by $35 \%$ of respondents who will probably visit the restaurants. Very less respondents of $3.3 \%$ and $1.7 \%$ definitely will not.[32]

\section{XIII.RESULTS}

Consumers are finally free from having to haggle their brains calculating various taxes on the final bill. For customers, the GST has made dining out more pocket-friendly with a single transparent $18 \%$ charge as opposed to the earlier multiple 20-24\% charges that were cumulatively levied.

Reduced food bill taxes by approx. 9.5 percent will be instrumental in attracting more restaurant clients.

Depending on the annual turnover, small-scale restaurant owners will profit from a minimum sheet of 5-12 percent tax or no tax.

The new GST system will assist generate income from the government, decrease corruption and decrease restaurant company expenses.

The budget and luxury hotel tax brackets are too broad.

In these budget hotels and luxury hotels, medium-sized restaurants will be unnecessarily taken into the tax slab of $28 \%$ tax.

This will impact footfalls in these hotels, thus directly and indirectly influencing restaurant footfalls.

The service fee is not a tax of government. This quantity is usually 10 percent of the food price you order. It is entirely a call from the customer whether or not they want to pay the service charge.

If the restaurant forces you to pay the service tax, you can sue the property in the consumer court

You have to pay two taxes separately: service tax and Value Added Tax. GST has now substituted both of them.

If you're dining in a non-AC restaurant, you'll have to pay a tax of $12 \%$. It consists of Central GST (6\%) and State GST $(6 \%)$.

$\square$ If you're in an AC restaurant, you'll have to pay a tax of $18 \%$ regardless of whether or not you're serving alcohol.

If the meals sold from restaurants are pre-packedand pre-cooked, you will have to pay a 12 percent tax.

What you need to understand is that liquor or liquor products are not subject to GST.
Liquor, as imposed by your state, will attract VAT. So, you pay GST on food and VAT on alcoholic beverages if you order alcoholic beverages and food.

In order to bring about a beneficial shift in the food and beverage industry, the fresh GST system has been suggested but only time will decide on its effect on the sector.[33]

\section{XIV.DISCUSSION}

If you are visiting a restaurant or cafe now that the Goods and Services Tax (GST) has been rolled out, your bill breakdown will look different from before GST. Since 1 July 2017, GST has subsumed 17 indirect taxes and 22 cessations at distinct prices across separate countries.Earlier a normal restaurant bill used to show a plethora of taxes which were charged by the state (VAT/sales tax) and the central government (Service tax) in addition to the service charge levied by the restaurant owners. Make yourself aware of the taxation charged on different slaps and let no restaurants fool you.A restaurant which has turnover less than ₹50 lakh is charged 5\% GST, a restaurant having turnover Higher than ₹50 lakh but do not have AC facility is charged $12 \%$ whereas a restaurant having AC facility is charged $18 \%$ GST. The GST rates increase to $28 \%$ for luxury restaurants and the five-star hotels

\section{XV.CONCLUSION}

Overall, trading on several commodities that was not regulated earlier has become more structured, for example, oilseeds, pulses, and cereals have been put under the light of a structured tax, and therefore can be accessed better in terms of both manufacture and consumption.There would be more transparency in business, as everything, from the purchase to the sale of the product or service would be documented. So we can reasonably assume that GST will bring reasons for rejoicing under the new system for both customers and restaurant owners, and we will have more reason to discover our neighborhood's fresh food joints.

\section{REFERENCES}

1) BharthVajan R., Ramachandran S.,Psychographic dimensions of training,2016,International Journal of Pharmacy and Technology,V-8,I-4,P-23727-23729

2) Balakrishnan P., Bharthvajan R.,A study on human resource planning in hospitals in Chennai City,2014,International Journal of Applied Engineering Research,V-9,I-22,P-7503-7507

3) Priyadarsini P., Bharthvajan R.,Role of emotional intelligence training programme in reducing the stress of the nurses,2014,International Journal of Applied Engineering Research,V-9,I-22,P-7411-7421

4) Kerinab Beenu G., Bharthvajan R.,Empirical analysis on the cosmetic buying behavior of young women in South India,2014,International Journal of Applied Engineering Research,V-9,I-22,P-7361-7366

5) Balakrishnan P., Bharthvajan R.,Whistling in the wind,2014,International Journal of Applied Engineering Research,V-9,I-22,P-7586-7593

6) Krishnan B., Peter M.,Health hazards of Indian Bpo employee-an alarming issue,2014,International Journal of Applied Engineering Research,V-9,I-22,P-7336-7341

7) Kerinab Beenu G.H., Peter M.,Role of insurance in economic development,2014,International Journal of Applied Engineering Research,V-9,I-22,P-7532-7539

8) Balakrishnan P., Peter M., Priyadarsini P.,Efficiency of safety measures for wellbeing of employees in manufacturing industry,2014,International Journal of Applied Engineering Research,V-9,I-22,P-7376-7382 
9) Anbarasi M., Praveen Kumar S.,Online sales promotions of herbal products and its effectiveness towards tanisha.com,2019,Indian Journal of Public Health Research and Development,V-10,I-1,P-195-200

10) Anbarasi M., Praveen Kumar S.,Various online marketing and promotions strategies to improve the validation towards the organic products in the pharmaceutical sectors,2019,Indian Journal of Public Health Research and Development,V-10,I-1,P-263-269

11) Loganathan R., Praveen Kumar S.,Grievance handling a key factor for solving issues of employees in an organization,2014,International Journal of Applied Engineering Research,V-9,I-22,P-7483-7491

12) Loganathan R., Praveen Kumar S.,Study on preference of private label brands in super and Hypermarkets,2014,International Journal of Applied Engineering Research,V-9,I-22,P-7327-7335

13) Smitha M., Praveen Kumar S.,Understanding stress and its managementamong the nurses in Chennai city,2014,International Journal of Applied Engineering Research,V-9,I-22,P-7560-7565

14) Kerinab Beenu G.H., Praveen Kumar S.,A study on the investment behavior of Chennai investors in mutual fund schemes,2014,International Journal of Applied Engineering Research,V-9,I-22,P-7520-7525

15) Loganathan R., Praveen Kumar S.,Retention strategies key for organizational productivity,2014,International Journal of Applied Engineering Research,V-9,I-22,P-7443-7447

16) Pavithra J., Ganesan M., Brindha G.,State wise analysis of microfinance sector in India,2016,International Journal of Pharmacy and Technology,V-8,I-4,P-23417-23432

17) Pavithra J., Ganesan M.,A comparative study on microfinance in India and abroad,2016,International Journal of Applied Business and Economic Research,V-14,I-8,P-5471-5476

18) Pavithra J., Ganesan M.,A study on awareness and impact of micro-financial schemes,2016,International Journal of Applied Business and Economic Research,V-14,I-8,P-5449-5460

19) Senthilmurugan P., Pavithra J.,Consumer preference towards organised retailing with reference to Big Bazaar,2014,International Journal of Applied Engineering Research,V-9,I-22,P-7469-7475

20) Senthilmurugan P., Pavithra J.,Implication of social media marketing in growing healthcare industry,2014,International Journal of Applied Engineering Research,V-9,I-22,P-7448-7456

21) Loganathan R., Pavithra J.,Consumer perception towards private label brand over other brands in super markets and hypermarkets,2014,International Journal of Applied Engineering Research,V-9,I-22,P-7355-7360

22) Kerinab Beenu G., Pavithra J.,Tradeâ€"off between liquidity and profitability in logistics industry,2014,International Journal of Applied Engineering Research,V-9,I-22,P-7398-7401

23) Kerinab Beenu G., Pavithra J.,A study on the prospective consumerâ $€^{\mathrm{TM}_{\mathrm{S}}}$ perception towards utility cars in Chennai city,2014,International Journal of Applied Engineering Research,V-9,I-22,P-7526-7531

24) Pavithra J., Dilli Babu P., Ambuli T.V.,A study on budgetary control at Maruti Service Masters, Chennai,2014,International Journal of Applied Business and Economic Research,V-12,I-2,P-151-161

25) Pavithra J., Dilli Babu P., Ambuli T.V.,A study on customer satisfaction of retro Garments Pvt Ltd, Chennai,2014,International Journal of Applied Business and Economic Research,V-12,I-2,P-381-391

26) Kerinab Beenu G.H., Pavithra J., Senthilmurugan P.,A study on the influence of promotional activities for TATA ARIA among consumers in Chennai,2014,International Journal of Applied Engineering Research,V-9,I-22,P-7572-7578

27) Vijayaragavan S.P.,An investigative expert that's general FBG sensors,International Journal of Mechanical Engineering and Technology,V-8,I-8,PP-1500-1505,Y-2017

28) Vijayaragavan S.P.,Equalization routing protocol for $\mathrm{Wi}-\mathrm{Fi}$ sensor strategy,International Journal of Mechanical Engineering and Technology,V-8,I-8,PP-1662-1666,Y-2017

29) Karthik B., Kiran Kumar T.V.U., Vijayaragavan P., Bharath Kumaran E.,Design of a digital PLL using 0.35 $\hat{\mathrm{I}}^{1} / 4 \mathrm{~m}$ CMOS technology,Middle East Journal of Scientific Research,V-18,I-12,PP-1803-1806,Y-2013

30) Kanniga E., Selvaramarathnam K., Sundararajan M.,Kandigital bike operating system,Middle - East Journal of Scientific Research,V

31) Jasmin M., Vigneshwaran T., Beulah Hemalatha S.,Design of power aware on chip embedded memory based FSM encoding in FPGA,International Journal of Applied Engineering Research,V-10,I-2,PP-4487-4496,Y-2015

32) Jasmin M.,Optimization techniques for low power VLSI circuits,Middle - East Journal of Scientific Research,V-20,I-9,PP-1082-1087,Y-2014

33) Jasmin M., Vigneswaran T.,Fuzzy controller for error control of on Chip communication,2017 International Conference on Algorithms,
Methodology, Models and Applications in Emerging Technologies, ICAMMAET 2017,V-2017-January,I-,PP-1-5,Y-2017

\section{AUTHORS PROFILE}

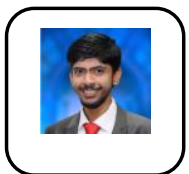

Gowtham Aashirvad Kumar, Assistant Professor Department of Management Studies,Bharath Institute of Higher Education and Research

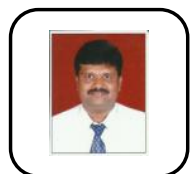

A.Ravikumar Assistant Professor Department of Management Studies,Bharath Institute of Higher Education and Research

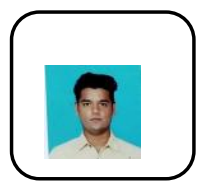

S.Mugundhan, Student Department of Management Studies,Bharath Institute of Higher Education and Research 